\title{
Computer Based Extension System and Competency of the Extension Professionals-A Study in Odisha
}

\author{
Santanu Patra $^{1^{*}}$, S. D. Mukhopadhyaya ${ }^{2}$ and R. K. Raj ${ }^{3}$ \\ ${ }^{1}$ Palli Siksha Bhavan, Sriniketan, Shantiniketan, India \\ ${ }^{2}$ Agril. Extension, Palli Siksha Bhawan, Shantiniketan, India \\ ${ }^{3}$ Agril. Extension, IAS, SOADU, Bhubaneswar, India \\ *Corresponding author
}

\section{A B S T R A C T}

\begin{tabular}{l} 
Ke y w o r d s \\
$\begin{array}{l}\text { Computer use, } \\
\text { Extension } \\
\text { professionals, } \\
\text { Competency, } \\
\text { Technology transfer }\end{array}$ \\
\hline Article Info \\
$\begin{array}{l}\text { Accepted: } \\
\text { 26 July 2020 } \\
\text { Available Online: } \\
\text { 10 August } 2020\end{array}$ \\
\hline
\end{tabular}

\section{Keywords}

Computer use, Extension Competency,

\section{Introduction}

The emergence of Information and Communication Technology has opened new avenues in knowledge management that play important roles in sharing, exchanging and disseminating knowledge in all fields (Angadi and Patel, 2013). The development of computers and advancements in communications provide numerous opportunities to obtain a variety of information particularly in Agriculture (Omidi et al., 2009). The computer and internet use have also been increased tremendously in Agricultural Extension Services (Chieochan et al., 2000).

Competency is an important determinant for successful implementation of computer technology and their sustained usage in the organisation (Compeau et al., 1999). It predicts both performance and behavior is choice (Gist et al., 1999). Increased performance with computer related tasks is also significantly related in higher level of competency (Harrison and Rainer, 1997). 
Simply introduction of computer assisted extension system will not solve the problems of the farming community, unless the extension professionals have competency in use of computers. The present study is an attempt to analyze the competency of the extension professionals in use of computers.

\section{Materials and Methods}

The study was undertaken in the state of Odisha during 2018. The extension professionals working in the state department of Agriculture, Horticulture, Watershed mission (Soil conservation), Animal resources and scientists of KrishiVigyanKendras (KVKs). The questionnaire developed for the purpose after pretesting was mailed to all the extension professionals working in these departments and KVKs. Were selected as the respondents for the study.

The questionnaire developed for the purpose after pre-testing was mailed to all the extension professionals working in these departments and KVKs. Only 174 extension professionals and $40 \mathrm{KVK}$ scientists have been responded by sending the filled questionnaires. The collected data was analysed with means core, critical ratio test, gap percentage and path analysis to reveal the results.

\section{Results and Discussion}

Access to computing resources is an important aspect of computer use. Access is mainly concerned with placement and availability of computers at ease. The respondents had favourably opined for their access (Table-1) in using printers and scanners, availability of common facilities and internet as well as availability of computers at their own desk in the office and at the time of need. But, the respondents had not much access in supply of stationaries and spare parts. However, the respondents had better access to computers.

Computer has diversified use particularly ward processing (Microsoft Word), spread sheets (Microsoft excel), presentation (Microsoft Power Point), net browsers (Microsoft internet explore), utilities (Winzip, Winrar, download accelerator etc.) CD / DVD writing (HP, Nero), Scanning and media player (Video, audio) etc. All these software applications are much needed for the computer assisted extension system. The extension professional should have adequate knowledge about all these applications. The data in Table-2 reflected that the respondents had better knowledge about application of Microsoft word, Microsoft excel, internet browsing, PDF, MS power point and to some extent media players. Knowledge about HP and Nero, Win Zip, download and acceleration as well as scanning software -HP etc. were not encouraging which needs further exposure to develop competency. However, the data in the table as a whole revealed that the respondents had good knowledge about various software applications.

Use of computers in completing specific tasks in extension system is an important dimensions in computer assisted extension system. It also justifies in purchasing the software. The data in Table- 3 revealed that the respondents were using computer in their various job tasks particularly desk top publishing, demonstration and to some extent data management as well as presentations. Poor job work was observed on video and photo editing, use of ICT as well as data analysis. However, the table as a whole revealed that the respondents were not much using computer in their job work. Further training and exposure are essentially required to develop the competency of the respondents for using computer in their various job works. 
Table.1 Access of the respondents towards computer

\begin{tabular}{|c|c|c|c|c|c|}
\hline \multirow{2}{*}{$\begin{array}{l}\text { Sl. } \\
\text { No. }\end{array}$} & \multirow[t]{2}{*}{ Access } & \multicolumn{2}{|c|}{ Mean Score } & \multirow{2}{*}{$\begin{array}{c}\text { Pooled mean } \\
\text { score } \\
(n=214)\end{array}$} & \multirow[t]{2}{*}{ Rank } \\
\hline & & $\begin{array}{l}\text { KVK Scientist } \\
\quad(n=40)\end{array}$ & $\begin{array}{c}\text { Extension functionary }(\mathrm{n} \\
=174)\end{array}$ & & \\
\hline i. & Own desk in the office & 2.40 & 2.34 & 2.35 & IV \\
\hline ii. & Common facilities available & 2.65 & 2.45 & 2.49 & II \\
\hline iii. & Internet facility available & 2.55 & 2.47 & 2.49 & II \\
\hline iv. & Using printers & 2.75 & 2.61 & 2.64 & I \\
\hline v. & Using scanners & 2.65 & 2.45 & 2.49 & II \\
\hline vi. & Supply of stationeries and spare parts & 2.25 & 1.90 & 1.96 & VI \\
\hline vii. & Computer facilities available at home & 2.33 & 2.18 & 2.21 & $\mathrm{~V}$ \\
\hline viii. & $\begin{array}{l}\text { Computer facilities available at the time } \\
\text { of need }\end{array}$ & 2.65 & 2.35 & 2.41 & III \\
\hline
\end{tabular}

(Always-3, some times-2 and never-1)

Table.2 Knowledge about various soft ware applications

\begin{tabular}{|c|c|c|c|c|c|}
\hline \multirow{2}{*}{$\begin{array}{l}\text { Sl. } \\
\text { No. }\end{array}$} & \multirow[t]{2}{*}{ Application } & \multicolumn{2}{|c|}{ Mean Score } & \multirow{2}{*}{$\begin{array}{c}\text { Pooled mean } \\
\text { score }(n=214)\end{array}$} & \multirow[t]{2}{*}{ Rank } \\
\hline & & $\begin{array}{c}\text { KVK Scientist }(n= \\
40)\end{array}$ & $\begin{array}{l}\text { Extension functionary } \\
\qquad(\mathrm{n}=\mathbf{1 7 4})\end{array}$ & & \\
\hline i. & Microsoft word & 2.65 & 2.64 & 2.64 & I \\
\hline ii. & Microsoft excel & 2.55 & 2.56 & 2.56 & II \\
\hline iii. & MS power point & 2.50 & 2.42 & 2.44 & V \\
\hline iv. & Internet browsing & 2.70 & 2.43 & 2.48 & III \\
\hline v. & Winzip, download, acceleration & 2.60 & 2.21 & 2.29 & VIII \\
\hline vi. & HP, Nero & 2.40 & 1.91 & 2.00 & IX \\
\hline vii. & Scanning software-HP etc. & 2.45 & 2.26 & 2.30 & VII \\
\hline viii. & Media player (Video, audio, mp-3 etc.) & 2.55 & 2.25 & 2.31 & VI \\
\hline ix. & PDF & 2.70 & 2.41 & 2.47 & IV \\
\hline
\end{tabular}

(Fully known-3, Partially known-2 and Not known-1)

Table.3 Extent of using computers in various job work

\begin{tabular}{|c|c|c|c|c|c|}
\hline \multirow{2}{*}{$\begin{array}{c}\text { Sl. } \\
\text { No. }\end{array}$} & \multirow[t]{2}{*}{ Use } & \multicolumn{2}{|c|}{ Mean Score } & \multirow[b]{2}{*}{$\begin{array}{c}\text { Pooled mean } \\
\text { score }(n=214)\end{array}$} & \multirow[t]{2}{*}{ Rank } \\
\hline & & $\begin{array}{l}\text { KVK Scientist } \\
(\mathrm{n}=\mathbf{4 0})\end{array}$ & $\begin{array}{l}\text { Extension functionary (n } \\
\quad=174 \text { ) }\end{array}$ & & \\
\hline i. & Demonstration & 2.65 & 2.25 & 2.33 & II \\
\hline ii. & Desktop publishing & 2.35 & 2.34 & 2.34 & I \\
\hline iii. & Data management & 2.45 & 2.23 & 2.27 & III \\
\hline iv. & Data analysis & 2.35 & 2.14 & 2.18 & V \\
\hline v. & Presentation & 2.40 & 2.20 & 2.23 & IV \\
\hline vi. & ICT & 2.15 & 1.83 & 1.89 & VI \\
\hline vii. & Photo editing & 2.18 & 1.77 & 1.85 & VII \\
\hline viii. & Video editing & 1.98 & 1.62 & 1.68 & VIII \\
\hline
\end{tabular}

(Frequently-3, Occasionally-2 and Never-1) 
Table.4 Level of expertise of the respondents on computer use

\begin{tabular}{|c|l|c|c|c|c|}
\hline \multirow{2}{*}{$\begin{array}{c}\text { Sl. } \\
\text { No. }\end{array}$} & \multicolumn{1}{|c|}{ Expertise } & KVK Scientist $\mathbf{( n = 4 0 )}$ & $\begin{array}{c}\text { Mean Score } \\
\text { Extension functionary } \\
(\mathbf{n = 1 7 4})\end{array}$ & $\begin{array}{c}\text { Rank } \\
\text { Pooled mean } \\
\text { score }(\mathbf{n}=\mathbf{2 1 4})\end{array}$ & \\
\hline i. & Microsoft word & 3.38 & 3.14 & 3.18 & I \\
\hline ii. & Microsoft excel & 3.23 & 3.02 & 3.06 & II \\
\hline iii. & MS power point & 3.33 & 2.84 & 2.93 & IV \\
\hline iv. & Internet browsing software & 3.23 & 2.90 & 2.96 & III \\
\hline v. & HP, Nero etc. & 2.88 & 2.16 & 2.29 & VII \\
\hline vi. & Scanning software-HP & 2.98 & 2.63 & 2.70 & V \\
\hline vii. & Media players (Audio, Video, & 3.13 & 2.52 & 2.63 & VI \\
\hline
\end{tabular}

(Hogh-4, Moderate-3, Little-2 and None-1)

Table.5 Extent of confidence level in use of computers

\begin{tabular}{|c|c|c|c|c|c|}
\hline \multirow[t]{2}{*}{ Sl. No. } & \multirow[t]{2}{*}{ Confidence } & \multicolumn{2}{|c|}{ Mean Score } & \multirow{2}{*}{$\begin{array}{c}\text { Pooled mean } \\
\text { score }(n=214)\end{array}$} & \multirow[t]{2}{*}{ Rank } \\
\hline & & $\begin{array}{c}\text { KVK Scientist (n } \\
=40)\end{array}$ & $\begin{array}{l}\text { Extension functionary (n } \\
=174)\end{array}$ & & \\
\hline 1. & Using user's guide as required & 2.70 & 2.27 & 2.35 & VI \\
\hline 2. & $\begin{array}{l}\text { Understanding terms / words on hard and soft } \\
\text { ware }\end{array}$ & 2.53 & 2.21 & 2.27 & VII \\
\hline 3. & Handling external hard disc correctly & 2.40 & 1.99 & 2.07 & $\mathrm{X}$ \\
\hline 4. & Using printers properly & 2.55 & 2.48 & 2.50 & II \\
\hline 5. & Copying compact disc / DVD & 2.60 & 2.13 & 2.22 & IX \\
\hline 6. & Copying file & 2.60 & 2.37 & 2.42 & $\mathrm{~V}$ \\
\hline 7. & Adding and deleting information from file & 2.55 & 2.40 & 2.43 & IV \\
\hline 8. & Getting help when problems arises & 2.43 & 2.20 & 2.24 & VIII \\
\hline 9. & Using local area network & 2.40 & 2.24 & 2.27 & VII \\
\hline 10. & Using internet & 2.50 & 2.44 & 2.45 & III \\
\hline 11. & Repairing minor problems & 1.80 & 1.68 & 1.70 & XII \\
\hline 12. & Proper maintenance of computer & 2.43 & 1.91 & 2.01 & XI \\
\hline 13. & Using pen drive & 2.60 & 2.58 & 2.57 & I \\
\hline
\end{tabular}

(Confident-3, Moderately confident-2 and Not confident-1)

Table.6 Comparative analysis of the competency in computer use

\begin{tabular}{|c|c|c|c|c|c|c|c|c|}
\hline \multirow{2}{*}{$\begin{array}{l}\text { Sl. } \\
\text { No. }\end{array}$} & \multirow[t]{2}{*}{ Competency } & \multirow{2}{*}{$\begin{array}{l}\text { Max. } \\
\text { Score }\end{array}$} & \multicolumn{2}{|c|}{ Mean Score } & \multirow{2}{*}{$\begin{array}{l}\text { Diff. } \\
(\%)\end{array}$} & \multirow{2}{*}{$\begin{array}{l}\text { C.R. } \\
\text { Value }\end{array}$} & \multirow{2}{*}{$\begin{array}{c}\text { Posted mean } \\
\text { score } \\
(n=214)\end{array}$} & \multirow{2}{*}{$\begin{array}{l}\text { Gap } \\
(\%)\end{array}$} \\
\hline & & & $\begin{array}{l}\text { KVK scientist } \\
(\mathrm{n}=\mathbf{4 0 )}\end{array}$ & $\begin{array}{c}\text { Extension } \\
\text { functionary }(n=174)\end{array}$ & & & & \\
\hline 1. & $\begin{array}{ll}\text { Access } \\
\text { computer }\end{array}$ & 3 & 2.53 & 2.34 & 7.51 & 0.071 & 2.38 & 20.67 \\
\hline 2. & $\begin{array}{l}\text { Software } \\
\text { application }\end{array}$ & 3 & 2.57 & 2.34 & 8.95 & 0.086 & 2.38 & 20.67 \\
\hline 3. & Use in job work & 3 & 2.31 & 2.05 & 11.25 & 0.091 & 2.10 & 30.0 \\
\hline 4. & Level of expertise & 4 & 3.17 & 2.74 & 13.56 & 0.148 & 2.82 & 29.50 \\
\hline 5. & Confidence & 3 & 2.47 & 2.22 & 10.12 & 0.095 & 2.27 & 24.33 \\
\hline
\end{tabular}


Computers in extension organisations are mostly used for office management and educational uses. The extension professionals should have expertise in both the aspects. The data reflected in Table- 4 revealed that the respondents had not much expertise on various aspects of computer use.

When the respondents had not adequate knowledge on various software applications, it is natural that their level of expertise will be at low level. Therefore, competency through training and exposure are essentially require to develop their expertise to shoulder the responsibilities in effective dissemination of technologies through computer.

Computer assisted extension system will be functional only when the extension professionals have confidence in use of computers. They need to be well versed with the operation of various job works from the farmer's perspective. Poor confidence level of the respondents were observed (Table-5) on repairing of minor problems, proper maintenance of the computer, handling external hard disc correctly, copying compact disc / DVD, using local area network and understanding terms / words on hard and software. However, better expertise were observed on using pen drive, printers and internet, adding and deleting information from file, copying file as well as using user's guide when required.

Comparative analysis revealed that (Table-6) both the extension functionary and KVK scientist respondents were of similar opinions as no significant differential gap percentage were observed through critical ratio test. Better responses were observed on access to computer and software applications. Significant percentage of gaps was observed on use of computers in job work, expertise and confidence level.
Path analysis revealed that service places of the respondent had highest indirect effect concluding that the service places channelised through extension activities undertaken, education, age, computer devices and communication channels used had exhibited significant influence in developing competency of the respondents in computer use.

In conclusion the govt. of India has stressed for the extensive use of modern information technology to promote communication between extension professionals and their farmer clients in transfer technologies and information more cost effectively. The extension professionals should therefore develop competency in use of computers in the process of technology transfer. The study revealed that the respondents had good access towards computer, knowledge on various software applications and using computers in their extension related job work. But, they had not adequate expertise and confidence level in using computer for effective transfer of technologies.

The findings therefore concluded that the extension professionals have to be exposed to training and exposure to develop their competency particularly on video and photo editing, repairing of minor problems, expertise in HP, Nero etc., ICT use in computer, expertise in media player, proper maintenance of computer, expertise in scanning software, data analysis, handling external disc correctly and expertise in MS power point along with adequate financial support enabling them to develop their expertise and confidence level for effective implementation of computer based extension system.

\section{References}

Angadi, U.B. and Patil, S.S. (2013): Network based knowledge management system 
in Indian Agricultural Extension, International Journal of Agricultural Sciences and Veterinary medicine, 1(1): 75-81.

Chieochan, O., Lindley, D. and Dunn, T. (2000): Factors affecting the use of Information Technology in Thai Agricultural Co-operatives: A work in progress, The Electronic Journal of Information systems in developing countries, 2(1): 1-15.

Compeau, D., Higgins, C.A. and Huff, S. (1999). Social cognitive theory and individual reactions to computing technology. A longitudinal study, MIS Quarterly, 23(2): 145-158.

Gist, M.E., Schwoerer, C., and Rosen, B. (1999): Effects of alternative training methods on self-efficiency and performance in computer software training, Journal of applied psychology, 74: 884-891.

Harrison, A.W. and Rainer, R.R. (1997): Testing the self-efficacy-performance linkage of social-cognitive theory, Journal of social psychology, 137(1): 79-87.

Omidi, N.M., Hosseini, J.F. and Mirdamadi, M. (2009): A case study of requirements and challenges off Information and Communication Technology System to train Private Agricultural insurance brokers, American-Eurasian Journal of Agriculture and Environmental Sciences, 6(2): 152-159.

\section{How to cite this article:}

Santanu Patra, S. D. Mukhopadhyaya and Raj, R. K. 2020. Computer Based Extension System and Competency of the Extension Professionals-A Study in Odisha. Int.J.Curr.Microbiol.App.Sci. 9(08): 3415-3420. doi: https://doi.org/10.20546/ijcmas.2020.908.394 